\title{
Fig tree induced phytophotodermatitis
}

\author{
Ana Andrade Oliveira ำ , Joana Morais, Olga Pires, Inês Burmester
}

Internal Medicine, Hospital de Braga, Braga, Portugal

\section{Correspondence to} Dr Ana Andrade Oliveira; anaandradeoliveira100@gmail. com

Accepted 11 February 2020

\section{DESCRIPTION}

A 63-year-old man, without any history of cutaneous reactions, noticed the spontaneous appearance of a painful, non-pruritic maculopapular hyperpigmented rash on his arms and legs (figures 1 and 2). Four days after the emergence of the lesions he looked for medical aid since the rash was getting worse with a more painful sensation and burn-like lesions (figures 1 and 2). He was already performing local wound care and taking antihistamines. When questioned, he remembered that he had been

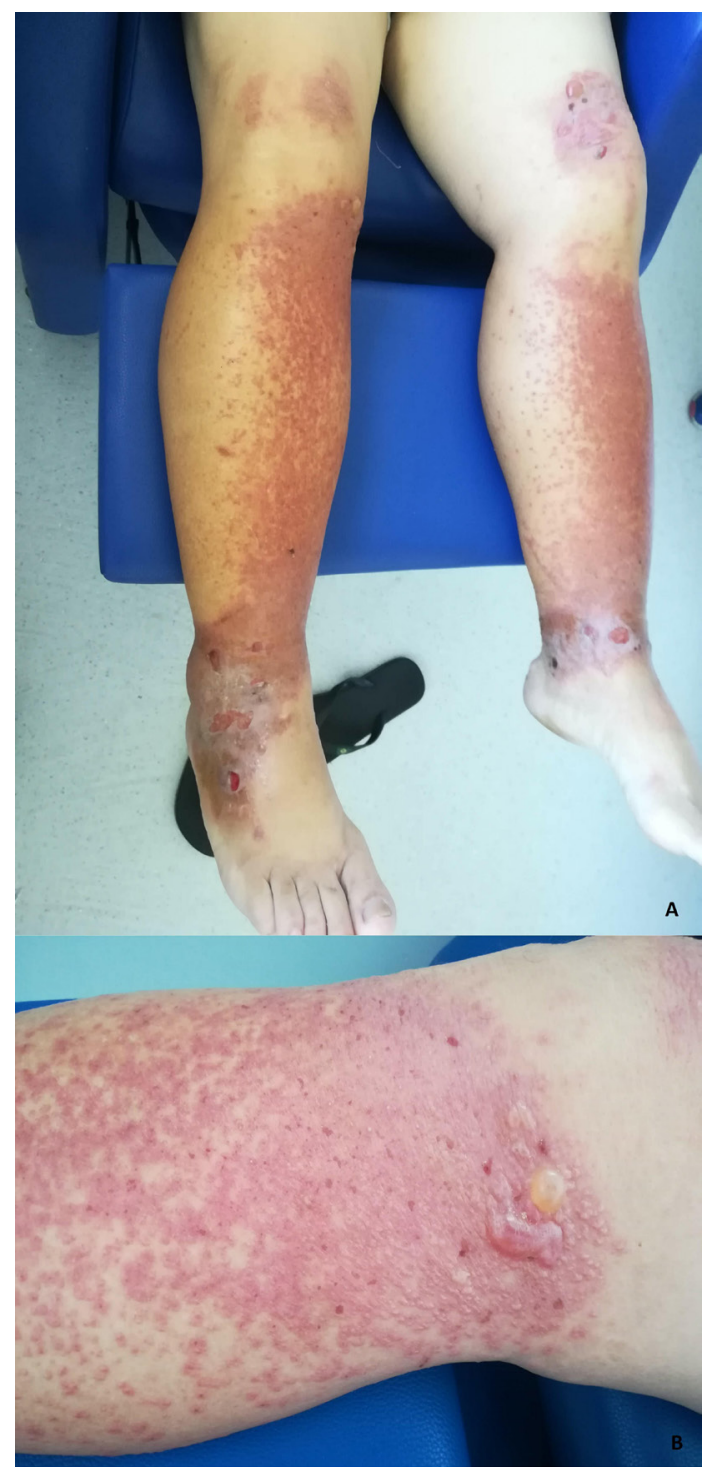

Figure 1 (A) Maculopapular exanthema on the anterior aspect of both legs; bullae with fluid above the left knee; erosions and postinflammatory hyperpigmentation on the malleolar region. (B) Erythema, vesicles and bullae in the proximal third of the right leg.

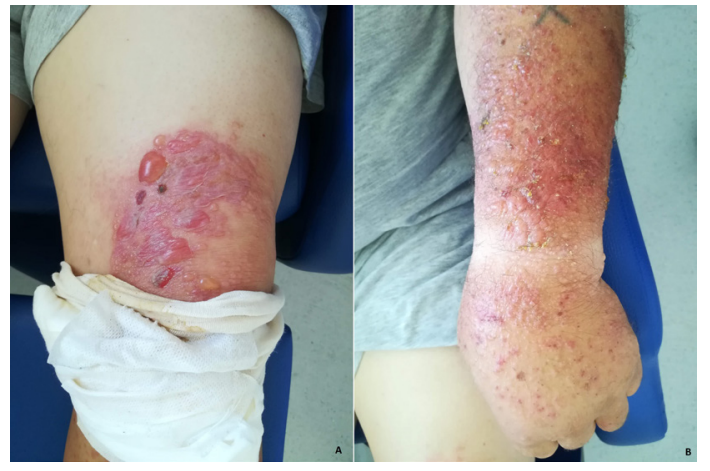

Figure 2 (A) Left knee showing multiple tense vesicles and bullae on an erythematous base. (B) Left arm with multiple erythematous papules and excoriated lesions.

pruning a fig tree under continuous sunlight exposure before the lesions started to appear. He recalled having directly contacted the sap of the fig tree on both arms and legs when pruning. He was wearing a t-shirt and shorts and had a watch on his left wrist. On physical examination, some lesions seemed infected with purulent drainage (figure 2). With the suggestive history, the distribution and pattern of lesions, fig tree induced phytophotodermatitis with superinfection was diagnosed. Symptoms and lesions gradually resolved with oral antibiotics, steroids and wound care.

Phytophotodermatitis represents non-immune mediated responses induced by furocoumarins that sensitise epithelial DNA to ultraviolet radiation causing 'burns induced by plants'. ${ }^{1-4}$ Fig tree leaves and sap contain photoactive furocoumarins that can cause this condition. ${ }^{2}$ Phytophotodermatitis is frequently confused with a broad spectrum of dermatological conditions like skin burns, drugrelated photosensitivity, herpetic lesions, bullous impetigo or contact dermatitis. ${ }^{14}$ A patient with a painful rash after direct exposure to plants known to contain furocoumarins, including limes, figs, celery, fennel, carrots, parsley, dill and parsnips, should raise consideration of the diagnosis of phytophotodermatitis. Infection can complicate severe lesions. ${ }^{14}$ Phytophotodermatitis is a

\section{Learning points}

Phytophotodermatitis must be suspected when a patient appears with an erythematous rash in sun-exposed areas after exposure to plants containing photoactive furocoumarins.

- The diagnosis is made based on the clinical history and can be confused with other skin conditions requiring a high index of suspicion. 
self-limited condition and care is typically focused on symptomatic management. However, in the presence of moderate lesions, topical steroids are indicated to reduce inflammation. ${ }^{14}$ In severe cases where the lesions cover a substantial area, oral steroids can be used. ${ }^{4}$ Antibiotics are traditionally reserved for bacterial superinfection. ${ }^{4}$ This is one of the most exuberant cases of phytophotodermatitis since most cases exhibit self-limited phytophotodermatitis.

Contributors $\mathrm{AAO}$ and $\mathrm{JM}$ are the first authors of the article. $\mathrm{OP}$ and $\mathrm{IB}$ analysed and corrected the article.

Funding The authors have not declared a specific grant for this research from any funding agency in the public, commercial or not-for-profit sectors.

Competing interests None declared.
Patient consent for publication Obtained.

Provenance and peer review Not commissioned; externally peer reviewed.

\section{ORCID iD}

Ana Andrade Oliveira http://orcid.org/0000-0002-8603-8020

\section{REFERENCES}

1 Hankinson A, Lloyd B, Alweis R. Lime-induced phytophotodermatitis. J Community Hosp Intern Med Perspect 2014;4. doi:10.3402/jchimp.v4.25090. [Epub ahead of print: 29 Sep 2014].

2 Bollero D, Stella M, Rivolin A, et al. Fig leaf tanning lotion and sun-related burns: case reports. Burns 2001;27:777-9.

3 Lagey K, Duinslaeger L, Vanderkelen A. Burns induced by plants. Burns 1995:21:542-3.

4 Picard C, Morice C, Moreau A, et al. Phytophotodermatitis in children: a difficult diagnosis mimicking other dermatitis. J Dermatolog Clin Res 2017;5:1101.

Copyright 2020 BMJ Publishing Group. All rights reserved. For permission to reuse any of this content visit

https://www.bmj.com/company/products-services/rights-and-licensing/permissions/

BMJ Case Report Fellows may re-use this article for personal use and teaching without any further permission.

Become a Fellow of BMJ Case Reports today and you can:

- Submit as many cases as you like

- Enjoy fast sympathetic peer review and rapid publication of accepted articles

- Access all the published articles

- Re-use any of the published material for personal use and teaching without further permission

\section{Customer Service}

If you have any further queries about your subscription, please contact our customer services team on +44 (0) 2071111105 or via email at support@bmj.com.

Visit casereports.bmj.com for more articles like this and to become a Fellow 